LETTERS

\title{
Activation dependent apoptosis of peripheral blood mononuclear cells from patients with rheumatoid arthritis treated with methotrexate
}

\author{
J Swierkot, R Miedzybrodzki, S Szymaniec, J Szechinski
}

Ann Rheum Dis 2004;63:599-600. doi: 10.1136/ard.2003.015370

A ctivation-induced apoptosis is a critical mechanism by which the immune system maintains tolerance to self antigens by the clonal deletion of autoreactive $\mathrm{T}$ and $\mathrm{B}$ cells. ${ }^{1}$ The involvement of apoptosis in the mechanism of cell death induced by high doses of methotrexate (MTX) was first demonstrated in Chinese hamster ovary cells. ${ }^{2}$ Fas mediated apoptosis may have a critical role in the regression of synovial hyperplasia in rheumatoid arthritis (RA). ${ }^{3}$ Cutolo et al demonstrated the influence of MTX on the proliferation and apoptosis of cultured human monocytic myeloid cells (THP-1). ${ }^{4}$ Genestier et al investigated the effect of low doses of MTX on human peripheral blood lymphocytes and showed that MTX could induce the in vitro apoptosis of mitogen activated lymphocytes $\mathrm{CD} 4^{+}$and $\mathrm{CD}^{+}$but not resting $\mathrm{T}$ cells. He also demonstrated that a single injection of MTX during low dose treatment in six patients with RA was sufficient to prime lymphocytes to apoptosis upon subsequent mitogenic activation ex vivo. ${ }^{5}$

The purpose of our investigation was to examine the influence of MTX on the apoptosis of in vitro phytohaemagglutinin (PHA) activated peripheral blood mononuclear cells (PBMC) from patients with RA subjected to MTX treatment, and its correlation with their clinical response.

\section{PATIENTS AND METHODS}

Investigations were carried out on 34 patients (aged 38-76 years) with active RA. MTX, 10-15 mg, was given orally once weekly. An assessment of these patients' clinical response to MTX according to the American College of Rheumatology criteria was made 8 weeks after beginning MTX treatment. ${ }^{6}$ Patients who had improved $\geqslant 20 \%$ compared with the baseline were defined as responders and patients with improvement $<20 \%$ were classified as non-responders. In the concomitant treatment one non-steroidal anti-inflammatory drug and prednisone (up to 7,5 mg daily) was allowed.

PBMC were isolated according to Böyum before MTX administration, activated with PHA $(5 \mu \mathrm{g} / \mathrm{ml})$ for 72 hours, and then washed and incubated with MTX $(0.1-100 \mu \mathrm{mol} / \mathrm{l})$ in 96 well plates in duplicate. ${ }^{7}$ Cell death was evaluated using Hoechst 33342 (apoptotic cells) and ethidium bromide (necrotic cells). Three hundred cells from each well were counted and the mean percentage of apoptotic cells calculated.

\section{RESULTS AND DISCUSSION}

There were no significant differences in the percentage of the MTX-induced $(0.1-100 \mu \mathrm{mol} / \mathrm{l})$ apoptosis of PHA activated PBMC derived from MTX treated patients with clinical improvement compared with the patients without improvement (fig 1). These results did not differ when compared with the results in the MTX untreated group. However, as in Genestier's study, MTX increased the specific apoptosis of PHA activated PBMC as compared with cells not activated with PHA (data not shown). ${ }^{5}$ Lack of differences in the in
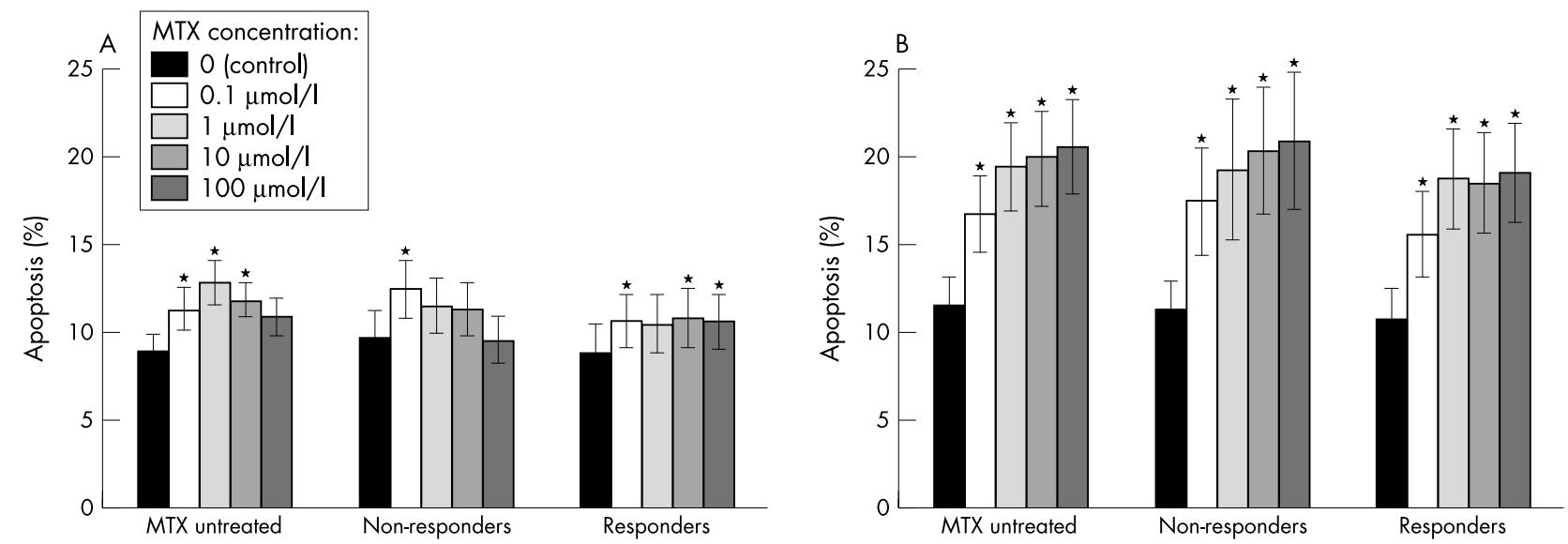

Figure 1 Percentage of in vitro MTX-induced apoptosis of PBMC derived from patients with RA (means (SEM)). (A) Apoptosis of PBMC not activated with PHA. (B) Apoptosis of PHA activated cells. *Significant differences in comparison with the control (Wilcoxon matched pairs test). Differences in apoptosis (at the same MTX concentration) between all studied groups were analysed using Kruskal-Wallis analysis of variance test. No significant differences were found either for non-activated or PHA activated cells. MTX untreated = patients with RA before they started MTX treatment ( $n=16$ ); responders $=$ patients with improvement of at least $20 \%$ according to ACR criteria $(n=13$; six patients $\geqslant 20 \%$ and seven patients $\geqslant 50 \%)$; nonresponders $=$ patients without improvement $(n=10)$. 
vitro MTX-induced apoptosis of PHA activated PBMC from MTX treated responding patients compared with the nonresponders indicates that this property may not be a good predictive factor for optimising MTX treatment.

Low dose MTX in RA treatment seems to exert antiinflammatory effects by acting at different levels of the pathophysiological cascade. ${ }^{8}$ Several studies have recently shown that low dose MTX may well induce antiproliferative effects on the immune cells owing to the inhibition of dihydrofolate reductase and folate dependent transmethylation as an independent mechanism of apoptosis. We did not confirm (unpublished data) that low dose treatment MTX was sufficient to prime PBMC to apoptosis upon subsequent PHA activation ex vivo. It is interesting that in Cutolo's experiments MTX at a concentration of $50 \mu \mathrm{g} / \mathrm{ml}$ did not induce apoptosis and did not affect the proliferation of RA synovial macrophages. ${ }^{4}$

It seems that either the apoptosis of cells in the tissue, which is directly involved in the inflammatory process, is more important than that seen in peripheral blood lymphocytes, or that other mechanisms of the MTX action may be responsible for the clinical improvement in patients treated with low doses of MTX.

\section{ACKNOWLEDGEMENTS}

This study was supported by the Polish State Committee for Scientific Research (KBN), grant No 4 P05B 10819.

Jerzy Swierkot and Ryszard Miedzybrodzki contributed equally to this work.

We thank Mrs Barbara Bubak MSc and Mrs Wiesława Kilian for their skilful assistance.

\section{Authors' affiliations}

J Swierkot, J Szechinski, Medical University Wroclaw, Poland

R Miedzybrodzki, S Szymaniec, Institute of Immunology and

Experimental Therapy, Polish Academy of Sciences, Wroclaw, Poland

Correspondence to: Dr J Swierkot, Medical University Wroclaw, ul. Wisniowa 36 Wroclaw, Poland 53-137; jurekswierkoł0@poczta.onet.pl

Accepted 6 September 2003

\section{REFERENCES}

1 Mountz JD, Zhou T, Su X, Wu J, Cheng J. The role of programmed cell death as an emerging new concept for the pathogenesis of autoimmune diseases. Clin Immunol Immunopathol 1996;80(3 Pt 2):S2-14.

2 Barry MA, Behnke CA, Eastman A. Activation of programmed cell death (apoptosis) by cisplatin, other anticancer drugs, toxins and hyperthermia. Biochem Pharmacol 1990:40:2353-62.

3 Kobayashi T, Okamoto K, Kobata T, Hasumana T, Nishioka K. Apomodulation as a novel therapeutic concept for the regulation of apoptosis in rheumatoid synoviocytes. Cur Opin Rheumatol 1999;1 1:188-93.

4 Cutolo M, Bisso A, Sulli A, Felli L, Briata M, Pizzorni C, et al. Antiproliferative and antiinflammatory effects of methotrexate on cultured differentiating myeloid monocytic cells (THP-1) but not on synovial macrophages from patients with rheumatoid arthritis. J Rheumatol 2000;27:2551-7.

5 Genestier L, Paillot R, Fournel S, Ferraro C, Miossec P, Revillard JP. Immunosuppressive properties of methotrexate: apoptosis and clonal deletion of activated peripheral T cells. J Clin Invest 1998;102:322-28.

6 Felson DT, Anderson JJ, Boers M, Bombardier C, Furst D, Goldsmith C, et al. American College of Rheumatology. Preliminary definition of improvement in rheumatoid arthritis. Arthritis Rheum 1995:38:727-35.

7 Böyum A. Isolation of monuclear cells by one centrifugation, and of granulocytes by combining centrifugation and sedimentation at $1 \mathrm{~g}$. Scand J Clin Lab Invest Suppl 1968;97:77-89.

8 Cutolo M, Sulli A, Pizzorni C, Seriolo B, Straub RH. Anti-inflammatory mechanisms of methotrexate in rheumatoid arthritis. Ann Rheum Dis 2001;60:729-35

\title{
Platelet and endothelial activation are requisites for the development of antiphospholipid syndrome
}

\author{
E del Río García, C Rodríguez, J Rodríguez-Martorell, A Serrano, J A Girón-González
}

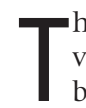
he antiphospholipid syndrome (APS) is characterised by venous and arterial thrombosis, recurrent fetal loss, and by the presence of antiphospholipid antibodies (aPL). aPL are also present in $2 \%$ of the healthy population, ${ }^{23}$ and, with the exception of those with high titres of aPL, there is no clear evidence of an increased incidence of thrombosis throughout the follow up. ${ }^{2-4}$ Thus, one of the key questions is: What causes the development of thrombosis in patients with APS? We suggest that in APS, a persistent procoagulant state, $^{56}$ a continuous endothelial and platelet activation is present, and this may be detected by raised levels of soluble adhesion molecules.

\section{METHODS AND RESULTS}

We prospectively studied the following groups of subjects: $(a)$ 20 patients with APS, $^{7} 10$ with primary disease and 10 associated with systemic lupus erythematosus; all had presented an arterial or venous thrombotic episode, or both; (b) 20 subjects with aPL but without any clinical finding (aPL WCF); in these subjects aPL were determined by the unexplained presence of an activated partial thromboplastin time inhibitor; (c) 20 healthy controls (HC).

Lupus anticoagulant was analysed by screening tests (dilute Russell viper venom time, dilute one stage prothrombin time, and sensitised partial thromboplastin time) and confirmed by the viper venom time with phospholipid excess and platelet neutralisation tests. ${ }^{8}$ Standardised enzyme linked immunosorbent assays (ELISAs) were used to measure serum levels of anticardiolipin antibodies (Orgentec Diagnostika, Mainz, Germany) ${ }^{9}$; immunoglobulin G anti- $\beta_{2^{-}}$ glycoprotein I (anti- $\beta_{2}$ GPI) (IMMCO Diagnostic, Buffalo NY, USA $)^{10}$; and platelet (P-selectin) and endothelial (E-selectin and intercellular cell adhesion molecule-1, ICAM-1) adhesion molecules (R\&D, Minneapolis, USA). In patients with APS, soluble adhesion molecules were measured at the time of the second determination of aPL ( 8 weeks after thrombosis or after parturition).

At least the lupus anticoagulant or increased serum levels of one of the isotypes of anticardiolipin antibodies was detected in all subjects with APS or aPL WCF. Serum concentrations of anti- $\beta_{2}$ GPI above the normal range were detected in all patients with APS and in $30 \%$ of the subjects with aPL WCF.

Those subjects with APS and with aPL WCF all showed increased concentrations of E-selectin, in comparison with HC. P-selectin levels were only significantly increased in patients with APS. ICAM-1 concentrations were similar in each of the groups (table 1). Patients with primary or 
Table 1 Characteristics of patients with antiphospholipid syndrome and controls

\begin{tabular}{|c|c|c|c|c|c|}
\hline \multirow[b]{2}{*}{ Parameter } & \multicolumn{3}{|c|}{ Patients with antiphospholipid syndrome } & \multicolumn{2}{|l|}{ Controls } \\
\hline & $\begin{array}{l}\text { Overall } \\
(n=20)\end{array}$ & $\begin{array}{l}\text { Primary) } \\
(n=10\end{array}$ & $\begin{array}{l}\text { Secondaryt } \\
(n=10)\end{array}$ & $\begin{array}{l}\text { Subjects with aPL } \\
\text { without clinical findings } \\
(\mathrm{n}=20 \text { ) }\end{array}$ & $\begin{array}{l}\text { Healthy controls } \\
(n=20)\end{array}$ \\
\hline Age (years) & $39.4(13.2)$ & $36.8(15.4)$ & 43.5 (11.8) & $47.2(17.8)$ & $43.2(6.1)$ \\
\hline Men:women ratio & $1.7: 1$ & $1.7: 1$ & $1.8: 1$ & $1.7: 1$ & $1.7: 1$ \\
\hline \multicolumn{6}{|l|}{ Clinical findings (\%) } \\
\hline Venous thrombosis & 65 & 60 & 70 & 0 & 0 \\
\hline Arterial thrombosis & 40 & 50 & 30 & 0 & 0 \\
\hline Abortions & 20 & 20 & 20 & 0 & 0 \\
\hline Anticardiolipin antibodies lgG $\ddagger$ & & & & & $0^{* *}$ \\
\hline Percentage above normal & 50 & 50 & 50 & 70 & \\
\hline Mean titre (GPL/ml) & $19.0(18.3)$ & $18.6(17.7)$ & $19.5(19.0)$ & $28.4(19.1)$ & 0 ** \\
\hline \multicolumn{6}{|l|}{ Anticardiolipin antibodies lgM } \\
\hline Percentage above normal & 55 & 50 & 60 & 30 & 0 ** \\
\hline Mean titre $(\mathrm{MPL} / \mathrm{ml})$ & $22.1(11.9)$ & $24.0(9.6)$ & $20.3(13.2)$ & 45.0 (33.9) & $0 * *$ \\
\hline \multicolumn{6}{|l|}{ Lupus anticoagulant } \\
\hline Percentage above normal & 30 & 10 & 50 & 20 & $0^{*}$ \\
\hline \multicolumn{6}{|l|}{ Anti- $\beta_{2}$-glycoprotein antibodies $\S$} \\
\hline Percentage above normal & 100 & 100 & 100 & 30 ** & $0^{* *}$ \\
\hline Mean titre (IU/ml) & $134.3(76.5)$ & $95.2(30.0)$ & $175.3(106.6)$ & $13.8(9.7)^{\star *}$ & 0 ** \\
\hline \multicolumn{6}{|l|}{ E-selectin } \\
\hline Mean titre $(\mathrm{ng} / \mathrm{ml})$ & $65.8(16.5)$ & $69.8(14.5)$ & $63.0(19.6)$ & $52.4(24.1)$ & $42.6(10.5)^{\star \star *}$ \\
\hline \multicolumn{6}{|l|}{ P-selectin } \\
\hline Mean titre (ng/ml) & $213.2(92.5)$ & $254.3(107.6)$ & $184.0(89.5)$ & $28.0(18.2)^{* *}$ & $29.5(12.3)^{* *}$ \\
\hline \multicolumn{6}{|l|}{ Intercellular adhesion molecule-1 } \\
\hline Mean titre $(\mathrm{ng} / \mathrm{ml})$ & $331.4(87.2)$ & $296.9(79.0)$ & $363.5(107.6)$ & $314.2(116.0)$ & $206.1(64.8)$ \\
\hline
\end{tabular}

secondary APS showed similar concentrations of the adhesion molecules. There was no difference between patients with arterial or venous thrombosis or abortions in respect of these measures (data not shown).

All the patients with APS were treated with dicumarin, maintaining an international normalised ratio of more than 3. During a follow up of 18 months, no significant clinical event was noted. Likewise, no significant change was detectable in the percentage of positivity or in the mean titres of aPL or adhesion molecules.

\section{DISCUSSION}

These results demonstrate that the presence of aPL, with or without clinical findings, is linked to increased levels of Pselectin, a marker of endothelial activation; however, serum concentration of ICAM-1, a molecule that mediates the firm adhesion of circulating cells, was normal. Owing to the absence of clinical events during the follow up, we cannot rule out the possibility of an increased expression of ICAM-1 in relation to the appearance of new thrombi.

The presence of simultaneously increased levels of Pselectin in patients with APS supports the suggestion of a platelet activation state as the explanation for the clinical findings in this disease. The persistence of raised levels of adhesion molecules rules out an increased expression of these antigens as a consequence of the recent thrombosis or abortions.

\section{Authors' affiliations}

E del Río García, A Serrano, J A Girón-González, Servicios de Medicina Interna, Hospital Universitario "Puerta del Mar", Cádiz, Spain C Rodríguez, Inmunología, Hospital Universitario "Puerta del Mar", Cádiz, Spain
J Rodríguez-Martorell, Hematología, Hospital Universitario "Puerta del Mar", Cádiz, Spain

Correspondence to: Dr J A Girón-González, Servicio de Medicina Interna, Hospital Universitario "Puerta del Mar", avda Ana de Viya 21, 11009, Cádiz, Spain; joseantonio.giron@uca.es

Accepted 10 June 2003

\section{REFERENCES}

1 Levine JS, Branch W, Rauch J. The antiphospholipid syndrome. N Engl J Med 2002;346:752-63.

2 Ginsburg KS, Liang MH, Newcomer L, Goldhaber SA, Schur PH, Hennekens $\mathrm{CH}$, et al. Anticardiolipin antibodies and the risk of ischemic stroke and venous thrombosis. Ann Intern Med 1992;117:997.

3 Ginsberg JS, Wells PS, Brill-Edwards P, Donovan K, Moffatt K, Johnston M, et al. Antiphospholipid antibodies and venous thromboembolism. Blood 1995;86:3685-91.

4 Elias M, Eldor A. Thromboembolism in patients with the "lupus"-type circulating anticoagulant. Arch Intern Med 1984;144:510-15.

5 Kaplanski G, Cacoub P, Farnarier C, Marin V, Gregoire R, Gatel A, et al. Increased soluble vascular cell adhesion molecule 1 concentrations in patients with primary or systemic lupus erythematosus-related antiphospholipid syndrome: correlations with the severity of thrombosis. Arthritis Rheum 2000;43:55-64.

6 Joseph JE, Harrison P, Mackie IJ, Isenberg DA, Machin SJ. Increased circulating platelet-leucocyte complexes and platelet activation in patients with antiphospholipid síndrome, systemic lupus erythematosus and rheumatoid arthritis. Br J Haematol 2001;115:451-9.

7 Wilson WA, Gharavi AE, Koike T, Lockshin MD, Branch DW, Piette JC, et al. International consensus statement on preliminary classification criteria for definite antiphospholipid syndrome. Arthritis Rheum 1999:42:1309-11.

8 Brandt JT, Triplett DA, Alving B, Scharrer I. Criteria for the diagnosis of lupus anticoagulants: an update. Thromb Haemost 1995;74:1185-90.

9 Harris EN, Gharavi AE, Patel SP, Hughes GRV. Evaluation of the anticardiolipin antibody test: report of an international workshop held 4 April 1986. Clin Exp Immunol 1987;68:215-22.

10 Matsuura E, Igarashi Y, Fujimoto M, Ichikawa K, Suzuki T, Sumida T, et al. Heterogeneity of anticardiolipin antibodies defined by the anticardiolipin cofactor. J Immunol 1992; 148:3885-90. 


\title{
Disease modifying treatment and elective surgery in rheumatoid arthritis: the need for more data
}

\author{
A Jain, R Maini, J Nanchahal
}

Ann Rheum Dis 2004;63:602-603. doi: 10.1136/ard.2003.017640

D isease modifying antirheumatic drugs (DMARDs) have become the cornerstone of treatment for patients with rheumatoid arthritis. The use of these drugs during the perioperative period has caused debate amongst rheumatologists and surgeons. Concerns focus on their potential to increase the risk of infection by affecting the immune response. Rheumatoid patients are at increased risk of infection, ${ }^{1}$ and this is of concern after surgery. ${ }^{2}$ Orthopaedic surgery in rheumatoid patients is common, ${ }^{3}$ and while it may seem prudent to stop DMARD treatment before surgery, this may result in flare up of disease activity. The resultant loss of mobility would adversely affect outcome, particularly after orthopaedic procedures, where mobilisation is crucial for effective rehabilitation. ${ }^{2}{ }^{4}$

Early reports suggested that methotrexate should be stopped before rheumatoid surgery, as it was claimed to increase infection rates. Studies have since shown that this is not the case and methotrexate should be continued throughout the surgical period (table 1). The effect of other DMARDs during surgery has been less well documented. Grennan et al, using logistic regression analysis, showed that penicillamine, indometacin, cyclosporin, antimalarial drugs, and corticosteroids increased postoperative complications in rheumatoid patients. ${ }^{4}$ However, they concluded that the clinical significance of these findings was uncertain as their study had not been designed to look at the effects of these drugs on postoperative complications. Recently, we have shown that neither methotrexate nor steroids, when used alone or in combination, affect the postoperative infection rate, and we recommend that these drugs should not be stopped before elective rheumatoid hand surgery. ${ }^{2}$

Increasing numbers of rheumatoid patients are being treated with tumour necrosis factor $\alpha$ (TNF $\alpha)$ inhibitors. $\mathrm{TNF} \alpha$ has a pivotal role in host resistance and as a mediator of local inflammation, although etanercept does not appear to alter global immune function, ${ }^{5}$ and infliximab treatment restored antigen and mitogen induced lymphocyte proliferation in vitro. ${ }^{6}$ There are no clear guidelines on the use of

cytokine inhibitors during the perioperative period and data on surgical complications in these patients are scarce. Guidelines for the use of infliximab in Crohn's disease state that routine use of anti-TNF $\alpha$ cannot be recommended before surgery. ${ }^{7}$ However, the authors concede that no formal trial has been undertaken and, based on the opinion or experiences of an expert committee, surgery during and after infliximab treatment appeared to be safe. ${ }^{7}$

Despite the fact that serious infection rates in clinical trials were no higher in those rheumatoid patients taking TNF $\alpha$ inhibitors than in those receiving placebo, concerns remain about infection. ${ }^{8}$ With the lack of data on the use of anti$\mathrm{TNF} \alpha$ and surgery, most clinicians would advise a cautious approach. The UK distributors of infliximab recommend that surgery be deferred for 2-4 weeks after the last infusion and close postoperative surveillance maintained, although surgery soon after administration of the drug is not absolutely contraindicated. After surgery, patients should be monitored closely as the long term effects of TNF $\alpha$ inhibition may mask signs of infection. ${ }^{9}$ Anti-TNF $\alpha$ treatment could be restarted 3 weeks after surgery, when the incisions should have healed.

Like anti-TNF $\alpha$, trials of the interleukin 1 receptor antagonist anakinra showed that the infection rate was similar to that in patients receiving placebo. ${ }^{10}$ Currently there are no specific data on the use of anakinra perioperatively. Therefore, a cautious approach is again warranted, with close postoperative surveillance.

Increasing use of cytokine inhibitors means that more patients receiving these drugs are likely to require surgical procedures in the future, despite improved disease control. Because of the small number of these patients currently being treated by individual surgeons, pooling of data and multicentre trials are essential for the production of meaningful guidelines.

\section{ACKNOWLEDGEMENTS}

A Jain was funded by an Arthritis Research Campaign Clinical Research Fellowship. The sponsor had no role in writing of the report.

Table 1 Summary of published reports on the influence of methotrexate (MTX) on postoperative complications

\begin{tabular}{|c|c|c|c|c|c|c|}
\hline \multirow[b]{2}{*}{ Study } & \multirow[b]{2}{*}{ Study design } & \multirow{2}{*}{$\begin{array}{l}\text { Total number } \\
\text { of patients }\end{array}$} & \multirow{2}{*}{$\begin{array}{l}\text { Number of } \\
\text { patients receiving } \\
\text { MTX at time of } \\
\text { surgery }\end{array}$} & \multicolumn{2}{|c|}{ Percentage complication rate } & \multirow{2}{*}{$\begin{array}{l}\text { Should } \\
\text { methotrexate be } \\
\text { stopped before } \\
\text { surgery? }\end{array}$} \\
\hline & & & & Receiving MTX & No MTX & \\
\hline Bridges SL et al (1991) & Retrospective review & 38 & 19 & 21 & 0 & Yes \\
\hline Perhala RS et al (1991) & Retrospective chart review & 121 & 60 & 8.7 & 5.5 & No \\
\hline Sany J et al (1993) & Prospective randomised study & 64 & 32 & 10 & 12 & No \\
\hline Kasdan ML \& June L (1993) & Retrospective chart review & 42 & 15 & 0 & $N / R^{*}$ & No \\
\hline $\begin{array}{l}\text { Escalante A \& Beardmore TD } \\
\text { (1995) }\end{array}$ & Retrospective and prospective review & $\begin{array}{l}204 \text { (367 } \\
\text { procedures) }\end{array}$ & 66 Procedures & 12 & $N / R^{*}$ & No \\
\hline Carpenter MT et al (1996) & Prospective non-randomised study & 32 & 13 & 25 & 0 & Yes \\
\hline Grennan DM et al (2001) & Prospective randomised study & 388 & 88 & 2 & 12 & No \\
\hline Jain A et al (2002) & Retrospective chart review & 80 & 46 & 5 & 6 & No \\
\hline
\end{tabular}

*Specific data not recorded. 


\section{CONFLICT OF INTEREST STATEMENT}

The Kennedy Institute received a research grant and payment (according to the number of patients) for clinical trials of an antiTNF antibody from Centocor Inc, Malvern, Pennsylvania, USA. Professor Maini has acted as a consultant.

\section{Authors' affiliations}

A Jain, R Maini, Kennedy Institute of Rheumatology, Faculty of Medicine, Imperial College London, Charing Cross Hospital, Fulham Palace Road, London W6 8RF, UK

A Jain, Department of Plastic and Reconstructive Surgery, Faculty of Medicine, Imperial College London, Charing Cross Hospital, Fulham Palace Road, London W6 8RF, UK

J Nanchahal, Department of Hand and Peripheral Nerve Surgery, University of Sydney, Royal North Shore Hospital, St Leonards, New South Wales 2065, Australia

Correspondence to: MrA Jain, AJainUK@aol.com

Accepted 2 February 2004

\section{REFERENCES}

1 Doran MF, Crowson CS, Pond GR, O'Fallon WM, Gabriel SE. Frequency of infection in patients with rheumatoid arthritis compared with controls: a population-based study. Arthritis Rheum 2002;46:2287-93.
2 Jain A, Witbreuk M, Ball C, Nanchahal J. Influence of steroids and methotrexate on wound complications after elective rheumatoid hand and wrist surgery. J Hand Surg Am 2002;27:449-55.

3 Da Silva E, Doran MF, Crowson CS, O'Fallon WM, Matteson EL. Declining use of orthopedic surgery in patients with rheumatoid arthritis? Results of a long-term, population-based assessment. Arthritis Rheum 2003:49:216-20.

4 Grennan DM, Gray J, Loudon J, Fear S. Methotrexate and early postoperative complications in patients with rheumatoid arthritis undergoing elective orthopaedic surgery. Ann Rheum Dis $2001 ; 60: 214-17$

5 Moreland LW, Bucy RP, Weinblatt ME, Mohler KM, Spencer-Green GT, Chatham WW. Immune function in patients with rheumatoid arthritis treated with etanercept. Clin Immunol 2002;103:13-21.

6 Cope AP, Londei M, Chu NR, Cohen SBA, Elliott MJ, Maini RN, et al. Chronic exposure to tumor necrosis factor (TNF) in vitro impairs the activation of $T$ cells through the T cell receptor/CD3 complex; reversal in vivo by anti-TNF antibodies in patients with rheumatoid arthritis. J Clin Invest 1994;94:749-60.

7 Schrieber S, Campieri M, Colombel JF, van Deventer SJH, Feagan B, Fedorak $\mathrm{R}$, et al. Use of anti-tumour necrosis factor agents in inflammatory bowel disease. European guidelines for 2001-2003. Int J Colorectal Dis $2001 ; 16: 1-11$

8 Ellerin T, Rubin RH, Weinblatt ME. Infections and anti-tumor necrosis factor $\alpha$ therapy. Arthritis Rheum 2003;48:3013-22.

9 Baghai M, Osmon DR, Wolk DM, Wold LE, Haidukewych GJ, Matteson EL. Fatal sepsis in a patient with rheumatoid arthritis treated with Etanercept. Mayo Clin Proc 2001;76:653-6.

10 Nuki G, Bresnihan B, Bear MB, McCabe D. Long-term safety and maintenance of clinical improvement following treatment with anakinra (recombinant human interleukin-1 receptor antagonist) in patients with rheumatoid arthritis. Arthritis Rheum 2002;46:2838-46.

\title{
Shrinking central nervous system in systemic lupus erythematosus
}

\author{
C C Mok, A Mak, E Y K Tsui
}

$\mathrm{N}$ europsychiatric manifestations of systemic lupus erythematosus (SLE) are diverse and heterogeneous. We report a patient who experienced a flare of SLE with subacute transverse myelopathy. Magnetic resonance imaging (MRI) showed atrophy of the entire central nervous system (CNS). Apart from psychosis at SLE onset, there had not been any neuropsychiatric relapses. Progressive atrophy of the CNS should be recognised as an evolving feature of SLE, which may occur without overt neurological symptoms.

\section{CASE REPORT}

A 22 year old Chinese woman with SLE was admitted because of a 2 month history of progressive weakness in her legs and bladder dysfunction. Her SLE had been diagnosed 5 years previously when she presented with polyarthritis, malar rash, cytopenia, psychosis, positive anti-dsDNA, and anti-Ro. A computed tomographic (CT) scan of the brain and cerebrospinal fluid (CSF) findings were unremarkable. Steroid and cyclophosphamide were given, with complete response. She remained well while receiving prednisone and azathioprine maintenance. Five months before the current episode, she had a mild flare with leucopenia and fever, which was controlled by increasing the steroid dose.

On current admission, examination showed spastic paraparesis (muscle power grade $3 / 5$ ). The arms were spared. Pain and touch sensation at the S4 and S5 dermatomes had diminished. A neuropathic bladder was present, but there was no optic neuritis or livedo reticularis. A CT scan showed atrophy of the brain and calcification of the basal ganglia (fig 1). MRI showed diffuse thinning of the entire spinal cord without abnormal signals in the intramedullary regions (fig 2). CSF analysis was normal and an oligoclonal IgG band was absent. Her anticardiolipin antibodies and lupus anticoagulant were repeatedly negative. The complement levels and white cell count were both depressed, but the platelet count was normal. High dose steroid, oral cyclophosphamide, and aspirin were given with partial neurological recovery after 4 months. Her urinary catheter was weaned and she could manage to walk with aids.

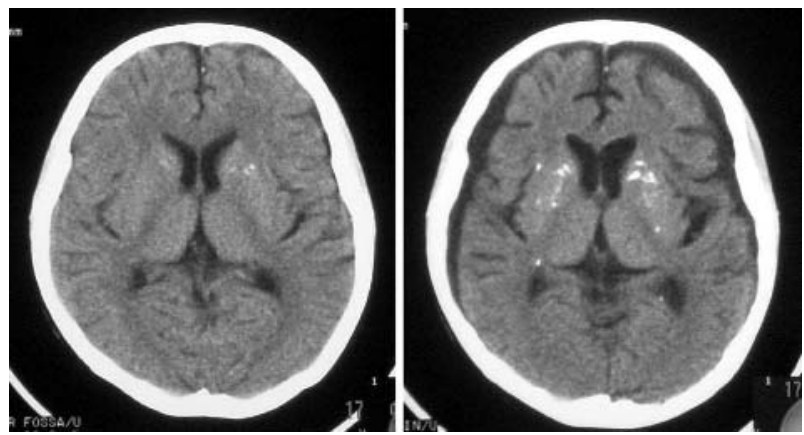

Figure $1 \mathrm{CT}$ scans of the brain at SLE diagnosis (A) and current presentation (B). 


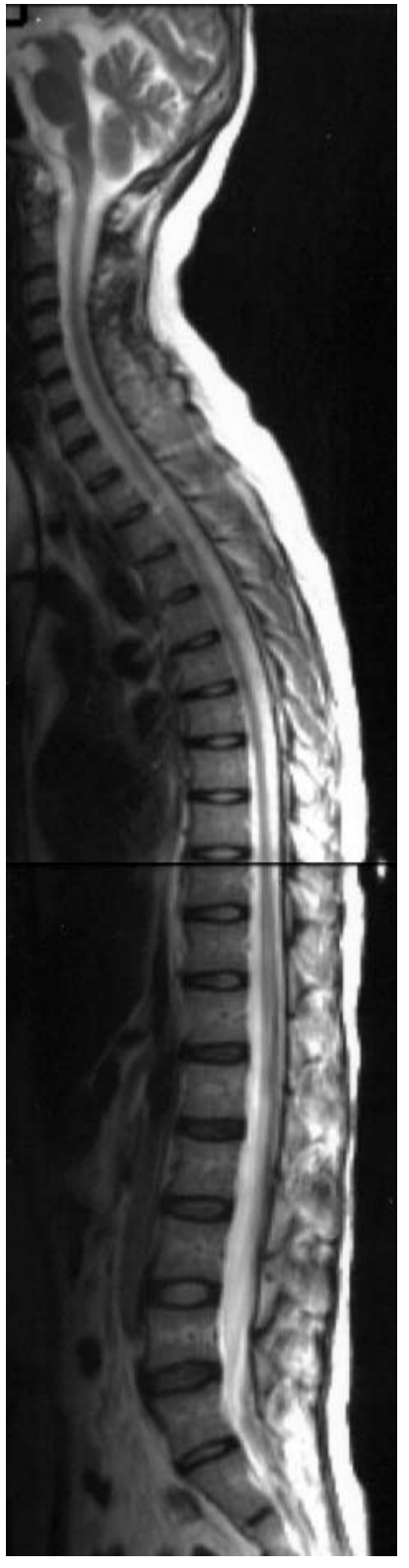

Figure 2 Sagittal $\mathrm{T}_{2}$ weighted MRI image showing diffuse atrophy of the entire spinal cord and the brain stem. No intramedullary signals were evident in the spinal cord.

\section{DISCUSSION}

Cerebral atrophy is reported in $32-71 \%$ of patients with SLE on CT/MRI scans and may develop rapidly after disease onset. $^{2-5}$ The degree of cerebral atrophy does not necessarily correlate with neurocognitive functioning, disease activity, or duration. ${ }^{2}{ }^{3}$ A case-control study demonstrated that cerebral atrophy was significantly more common in patients receiving long term corticosteroids than in healthy matched controls. The degree of atrophy was more severe in patients with SLE than in those without, indicating that factors intrinsic to SLE may also contribute. ${ }^{3}$ The greater severity of cerebral atrophy in patients with a history of neuropsychiatric SLE than in those without suggests that neuronal injury caused by previous immunological or vascular insult is an aggravating factor. $^{35}$

Transverse myelopathy (TM) is rare in SLE, occurring in less than $2 \%$ of patients. ${ }^{6}$ TM in SLE is associated with the antiphospholipid antibodies, which are prothrombotic and may stimulate endothelial cell proliferation and intimal fibrosis, leading to bland vasculopathy. ${ }^{78}$ The commonest MRI findings of SLE related TM are cord swelling and longitudinal $\mathrm{T}_{2}$ hyperdense signals crossing multiple spinal levels. ${ }^{6-9}$ Spinal cord thinning has been reported as a late sequela of lupus myelopathy despite successful treatment. ${ }^{10}$ Several explanations have been suggested. Ischaemia as a result of vasculitis or vascular thrombosis may mediate damage and demyelination of the cord. Cross reactivity or direct binding of certain existing or as yet unknown autoantibodies to antigens of the CNS may mediate axonal damage and global demyelination. CSF levels of interleukin (IL) 1, IL6, and interferon $\alpha$ are raised in patients with active neuropsychiatric SLE. ${ }^{1}$ ILl up regulates endothelial adhesion molecules and nitric oxide production, which may contribute to vascular inflammation and neuronal injury. IL6 stimulates neurotransmitter release and induces intrathecal synthesis of immunoglobulins. However, the exact role of cytokines in neuropsychiatric SLE remains speculative.

The incidental finding of CNS atrophy in our patient is apparently unrelated to the current episode of myelitis. The gradual evolution of cerebrospinal atrophy, the lack of ischaemic and inflammatory MRI signals, and the absence of antiphospholipid antibodies did not support thrombosis as the chief mechanism. Chronic use of steroids and neuronal insult at disease onset are possible explanations. Although the treatment and prognosis of CNS atrophy in SLE is virtually unknown, empirical aspirin and maintenance immunosuppression may be considered. Follow up MRI scans are needed to monitor the progress of CNS atrophy.

\section{Authors' affiliations \\ C C Mok, A Mak, Department of Medicine, Tuen Mun Hospital, Hong Kong \\ E Y K Tsui, Department of Radiology, Tuen Mun Hospital, Hong Kong}

Correspondence to: Dr C C Mok, Department of Medicine, Tuen Mun Hospital, Tsing Chung Koon Road, New Territories, Hong Kong; ccmok1@hgcbroadband.com

Accepted 4 June 2003

\section{REFERENCES}

1 West SG. Lupus and the central nervous system. Curr Opin Rheumatol 1996;8:408-14.

2 Waterloo K, Omdal R, Jacobsen EA, Klow NE, Husby G, Torbergsen T, et al. Cerebral computed tomography and electroencephalography compared with neuropsychological findings in systemic lupus erythematosus. J Neurol 1999:246:706-11.

3 Zanardi VA, Magna LA, Costallat LT. Cerebral atrophy related to corticotherapy in systemic lupus erythematosus (SLE). Clin Rheumatol 2001;20:245-50.

4 Chinn RJ, Wilkinson ID, Hall-Craggs MA, Paley MN, Shortall E, Carter S, et al. Magnetic resonance imaging of the brain and cerebral proton spectroscopy in patients with systemic lupus erythematosus. Arthritis Rheum 1997;40:36-46.

5 Ostrov SG, Quencer RM, Gaylis NB, Altman RD. Cerebral atrophy in systemic lupus erythematosus: steroid- or disease-induced phenomenon? Am J Neuroradiol 1982;3:21-3.

6 Tellez-Zenteno JF, Remes-Troche JM, Negrete-Pulido RO, DavilaMaldonado L. Longitudinal myelitis associated with systemic lupus erythematosus: clinical features and magnetic resonance imaging of six cases. Lupus $2001 ; 10: 851-6$.

7 Lavalle C, Pizarro S, Drenkard C, Sanchez-Guerrero J, Alarcon-Segovia D. Transverse myelitis: a manifestation of systemic lupus erythematosus strongly associated with antiphospholipid antibodies. J Rheumatol 1990;17:34-7.

8 Kovacs B, Lafferty TL, Brent LH, DeHoratius RJ. Transverse myelopathy in systemic lupus erythematosus: an analysis of 14 cases and review of the literature. Ann Rheum Dis 2000;59:120-4.

9 Mok CC, Lau CS, Chan EY, Wong RWS. Acute transverse myelopathy in systemic lupus erythematosus: clinical presentation, treatment, and outcome. J Rheumatol 1998;25:467-73.

10 Schantz V, Oestergaard LL, Junker P. Shrinking spinal cord following transverse myelopathy in a patient with systemic lupus erythematosus and the phospholipid antibody syndrome. J Rheumatol 1998;25:1425-8. 


\title{
Usefulness of glycosylated ferritin in atypical presentations of adult onset Still's disease
}

\author{
M A Hamidou, M Denis, S Barbarot, D Boutoille, C Belizna, G Le Moël
}

Ann Rheum Dis 2004;63:605. doi: 10.1136/ard.2003.012484

$M$ any diseases, such as infections, neoplasia, or immune diseases, can mimic adult onset Still's disease (AOSD). ${ }^{12}$ Atypical forms are not so rare, and the search for a diagnosis marker is warranted. Recently, the usefulness of low serum glycosylated ferritin (GF) was suggested. ${ }^{3-5}$

\section{CASE REPORT 1}

An 80 year old woman presented with 4 weeks' fever, myalgias, polyarthritis, and sore throat. Clinical examination disclosed a fixed generalised maculopapular rash, arthritis of wrists and ankles, and spleen enlargement. $\mathrm{C}$ reactive protein was $150 \mathrm{mg} / \mathrm{l}$, haemoglobin level $80 \mathrm{~g} / \mathrm{l}$, white blood count $30 \times 10^{9} / 1$ with $90 \%$ polymorphonuclear neutrophils, $10 \%$ lymphocytes, and $600 \times 10^{9} / 1$ platelets. Transaminases were twice the normal value $(2 \mathrm{~N})$. Ferritinaemia was $40000 \mu \mathrm{g} / \mathrm{l}$ (normal 50-300). Extensive investigations for infections, antinuclear and antineutrophil cytoplasmic antibodies, and rheumatoid factor were negative. Echocardiography, thoracic and abdominal computed tomographic scan, bone marrow biopsy, lumbar puncture were normal, except for splenomegaly. Skin biopsy disclosed unspecific urticarial lesions. The outcome was marked by high spikes of fever, general malaise with low blood pressure, hypoxaemia, suggesting systemic inflammatory response syndrome, and necessitating admission to an intensive care unit.

Empirical antibiotic treatment was ineffective. The blood white cell count was $42 \times 10^{9} / \mathrm{l}$, and ferritinaemia was $80000 \mu \mathrm{g} / \mathrm{l}$. The percentage of serum GF was $<5 \%$. Corticosteroid treatment improved the syndrome, with normalisation of the white blood count and ferritinaemia in 7 days. No systemic or neoplastic disease occurred with a follow up of 3 years.

\section{CASE REPORT 2}

A 51 year old woman presented to our department with 5 weeks' fever, sore throat, and myalgias. Clinical examination showed permanent maculopapular rash, and liver enlargement. C reactive protein was $120 \mathrm{mg} / \mathrm{l}$, haemoglobin $80 \mathrm{~g} / \mathrm{l}$, platelet count $30 \times 10^{9} / \mathrm{l}$, and white blood cell count $3 \times 10^{9} / 1$ with 800 polymorphonuclear neutrophils, 1200 lymphocytes, and 800 monocytes. Fibrinogen was $2 \mathrm{~g} / \mathrm{l}$, factor V 30\%, albuminaemia $22 \mathrm{~g} / \mathrm{l}$, transaminases $8 \mathrm{~N}$, and lactate dehydrogenase 3N. Ferritinaemia was $120000 \mu \mathrm{g} / \mathrm{l}$. Extensive infectious and immunological investigations were negative. Echocardiography, thoracic and abdominal computed tomographic scan, bone marrow biopsy, liver, skin, muscle, bone marrow biopsies were normal. Bone marrow aspiration disclosed haemophagocytosis features, according to the diagnosis of macrophage activation syndrome.

Empirical antimicrobial treatments were ineffective. GF was 3\%. Intravenous pulses of methylprednisolone and cyclosporin dramatically improved the course of the disease. With a follow up of 3 years, no systemic or neoplastic disease occurred.

\section{DISCUSSION}

Our case reports present atypical presentations of AOSD, with a fixed skin eruption, ${ }^{6}$ associated with a life threatening disease outcome in a very old person, and a macrophage activation syndrome ${ }^{7}$ in the other. Extensive investigations did not contribute to a diagnosis, and antimicrobial treatments were unsuccessful. Ferritinaemia was very high in both patients. There is no specific clinical or biological marker of AOSD. ${ }^{2}$ Low GF led us to the diagnosis of AOSD, and long term follow up validates this conclusion. The normal value of GF is $>50 \%$, and the serum level is not significantly modified by inflammation. The usefulness of a low GF value for diagnosis of AOSD was shown by Fautrel et al. ${ }^{5}$ In their study the percentage of GF was $<20 \%$ of the total ferritinaemia for 35 of 44 patients with AOSD, and for only 38 of 113 control patients with other inflammatory diseases. The combination of ferritinaemia fivefold above the upper normal value and a GF value $<20 \%$ had a specificity of $92.9 \%$ and a sensitivity of $43.2 \%$ for AOSD. GF could be a powerful diagnostic tool for AOSD, particularly in atypical clinical presentations of the disease.

\section{Authors' affiliations}

M A Hamidou, C Belizna, Department of Internal Medicine, Hôtel-Dieu Hospital, Nantes, France

M Denis, Biochemistry Laboratory, Hôtel-Dieu Hospital, Nantes, France S Barbarot, Department of Dermatology, Hôtel-Dieu Hospital, Nantes, France

D Boutoille, Department of Infectious Diseases, Hôtel-Dieu Hospital, Nantes, France

G Le Moël, Biochemistry A Laboratory, Bichat Hospital, Paris, France

Correspondence to: Dr M Hamidou, Service de Médecine Interne, Hôtel-Dieu, Place Alexis Ricordeau, Nantes, 44035 France; mohamed. hamidou@chu-nantes.fr

Accepted 4 December 2003

\section{REFERENCES}

1 Pouchot J, Sampalis JS, Beaudet F, Carette S, Décary F, SalusinskySternbach $M$, et al. Adult Still's disease: manifestations, disease course, and outcome in 62 patients. Medicine (Baltimore) 1991;70:118-36.

2 Yamaguchi M, Ohta A, Tsunematsu T, Kasukawa R, Mizushima Y Kashiwagi $\mathrm{H}$, et al. Preliminary criteria for classification of adult Still's disease. J Rheumatol 1992;19:424-30.

3 Van Reeth C, Le Moël G, Lasne Y, Revenant M-C, Agneray J, Kahn M-F, et al. Serum ferritin and isoferritins are tool for diagnosis of active adult Still's disease. J Rheumatol 1994;21:890-5.

4 Vignes S, Le Moël G, Fautrel B, Wechsler B, Godeau P, Piette J. Percentage of glycosylated serum ferritin remains low throughout the course of adult onset Still's disease. Ann Rheum Dis 2000;59:347-50.

5 Fautrel B, Le Moël G, Saint-Marcoux B, Taupin P, Vignes S, Rozenberg S, et al. Diagnostic value of ferritin and glycosylated ferritin in adult onset Still's disease. J Rheumatol 2001;28:322-9.

6 Suzuki K, Kimura Y, Aoki M, Takezaki S, Tuchida T, Takano T, et al. Persistent plaques and linear pigmentation in adult onset Still's disease. Dermatology 2001;202:333-5.

7 Kumakura S, Ishikura H, Munemasa S, Adachi T, Murakawa Y, Kobayashi S Adult onset Still's disease associated hemophagocytosis. J Rheumatol 1997;24:1654-8. 


\section{High grade heart block in association with SLE}

\section{S Edwards, R Mootoo, A Bhanji}

A 35 year old Afro-Caribbean man was referred by the dermatology department in March 2002. He had a 2 year history of a photosensitive rash, patchy alopecia, and a 1 year history of arthralgia affecting wrists, knees, and shoulders. He also described occasional night sweats. There was no history of thromboembolic events or migraine.

On examination he had two patches of alopecia and a small right knee effusion. His pulse was 64 beats per minute and regular, with a blood pressure of 120/70 and normal heart sounds. Otherwise his examination was unremarkable.

Investigations showed: positive antinuclear antibody (ANA; 1/160 homogeneous pattern); positive double stranded DNA on enzyme linked immunosorbent assay (ELISA) testing ( $169 \mathrm{IU} / \mathrm{ml}$; negative <40); extractable nuclear antigen negative for Ro, La, Sm, RNP, Jo-l antibodies; positive IgG anticardiolipin antibody ( $37 \mathrm{GPLU} / \mathrm{ml}$; negative $<14)$; normal complement C3 and low C4 (0.11 g/l; normal 0.16-0.47); normal full blood count including differential white cell count, renal and liver function, creatine kinase, erythrocyte sedimentation rate, and $\mathrm{C}$ reactive protein. His lupus anticoagulant test was also positive on two occasions. A diagnosis of systemic lupus erythematosus (SLE) was made.

Five years previously he had been investigated by the cardiologists for episodes of chest pain and dyspnoea. An initial ECG showed first degree heart block. A 24 hour ECG showed sinus rhythm with first degree heart block throughout, but also significant degrees of second degree heart block, and episodes of third degree block occurring at night with a maximum pause of 3.02 seconds. As he had no syncopal symptoms no further action was taken.

There was a family history of SLE in his mother, who had positive ANA and positive Ro and La antibodies.

\section{DISCUSSION}

Conduction defects in SLE are well described: congenital heart block in infants born to mothers with anti-Ro antibodies is the most widely known. These infants do not seem to have a greater risk of developing adult SLE than that conferred by maternal family history. Conduction disturbances in adults with SLE are rare but documented, in the form of all types of atrioventricular (AV) block, bundle branch block, sinus tachycardia, atrial fibrillation, and atrial ectopic beats. ${ }^{1}$ The prevalence of conduction defects may be as high as $10-14 \% .{ }^{12}$ Third degree block is very rare in adults with SLE-this is only the 11th case described. ${ }^{3}$ The pathology is thought to be nodal artery occlusive lesions with secondary collagen degeneration and fibrosis of AV and SA nodes. ${ }^{4-6}$
One study shows that anti-Ro antibody positive adults with SLE are more likely to have conduction defects than anti-Ro negative patients. ${ }^{7}$ This may provide a clue to the pathophysiology as anti-Ro antibodies are thought to be pathogenic in fetal heart block. However, other authors found conduction defects in only two of 33 patients with SLE, neither of whom was positive for Ro or La. The 12 patients with Ro or La antibodies, or both, did not have conduction problems. ${ }^{8}$ Although the detection of the antibodies was by differing techniques, overall the pathogenesis does not appear to be related to the presence of Ro or La antibodies.

In the case we describe, possible mechanisms are (a) varying degrees of intermittent heart block since birth and related to maternal Ro positivity; (b) nodal artery occlusive disease secondary to vasculitis; (c) idiopathic fibrosis; and least likely in view of his age, $(d)$ ischaemic heart disease.

This is the first description of high grade heart block predating the diagnosis of SLE. The occurrence of high grade heart block in young adults could prompt a search for other symptoms, signs, or laboratory tests of SLE.

\section{Authors' affiliations}

C S Edwards, R Mootoo, A Bhanii, Newham General Hospital, Forde's Cottage Hawkley Liss, Ha GU33 6LS, UK

Correspondence to: Dr C S Edwards; edwardscath@yahoo.co.uk

Accepted 26 July 2003

\section{REFERENCES}

1 Moder K, Miller T, Tazelaar H. Cardiac involvement in systemic lupus erythematosus. Mayo Clin Proc 1999;74:275-84.

2 Nagyhegyi G, Nadas I, Banyai F, Szongoth M, Luzsa G, Velics V, et al. Cardiac and cardiopulmonary changes in systemic lupus erythematosus. Orovsi Hetilap 1989;130:215-19.

3 Martinez-Costa X, Ordi J, Barbera J, Selva A, Bosch J, Vilardell M. High grade atrioventricular heart block in 2 adults with systemic lupus erythematosus. J Rheumatol 1991;18:1926-8.

4 James T, Rupe C, Monto R. Pathology of the cardiac conduction system in systemic lupus erythematosus. Ann Intern Med 1965:63:402-10.

5 Litsey S, Noonan J, O'Connor W, Cottrill C, Mitchell B. Maternal connective tissue disease and congenital heart block. N Engl J Med 1985;312:98-100.

6 Chang R. Cardiac manifestations of SLE. Clin Rheum Dis 1982;8:197-206.

7 Logar D, Kveder T, Rozman B, Dobovisek J. Possible association between antiRo antibodies and myocarditis or cardiac conduction defects in adults with systemic lupus erythematosus. Ann Rheum Dis 1990;49:627-9.

8 O'Neill T, Mahmoud A, Tooke A, Thomas R, Maddison P. Is there a relationship between subclinical myocardial abnormalities, conduction defects and Ro/La antibodies in adults with systemic lupus erythematosus? Clin Exp
Rheumatol 1993;11:409-12. 